\title{
KNOWLEDGE OF EPHRAIM'S WRITINGS IN THE MEROVINGIAN AND CAROLINGIAN AGE
}

\author{
DAVID GANZ \\ DEPARTMENT OF CLASSICS \\ KING'S COLLEGE \\ LONDON
}

[1] This paper is a statement of problems, rather than any attempt at their premature resolution. Fundamental questions about the reception of Ephraim's works in the Latin West, such as when and where the Latin translation was made, or what factors determined its popularity, await investigation. Prior to such investigation the evidence of transmission is our clearest evidence for the reception of the Latin Ephraim. I shall suggest that it is unlikely that his works were widely known, but that they constituted a representative aspect of early medieval spirituality. That spirituality still awaits its historian: the writings of Ephraim do not fit readily into the history of exegesis or of theological development. Standard accounts of Carolingian thought say nothing about his influence, or his importance. Indeed to discuss Ephraim may be entirely premature; until we have an available text of the Latin Ephraim and can investigate borrowings from that text in the writings of early medieval authors, our knowledge of his influence is utterly incomplete. ${ }^{1}$ Jerome included him in his de viris inlustribus, and had

1 For the most recent discussion of the text of the Latin Ephraim, cf. T.S. Pattie, "Ephraim the Syrian and the Latin Manuscripts of the De Paenitentia," British Library Journal 13 (1987): 1-27. I am grateful to Dr. 
read a Greek version of his treatise on the Holy Spirit, though he lists no other writings. ${ }^{2}$ But the absence of explicit mention of Ephraim in Carolingian accounts of theological writings suggests that his influence was small. ${ }^{3}$

The florilegium entitled Liber Scintillarum, the book of sparks from the words of God and of his saints, was composed by the monk Defensor of Ligugé. ${ }^{4}$ Our evidence for the life and date of Defensor derives entirely from his preface. He tells us that he was asked and instructed in how to write it by his teacher Ursinus. "Just as sparks come from a fire so here short sentences from the many books of the scriptures will be found shining." He emphasizes that he has identified the authors he quotes lest his work be thought apocryphal and without an author. ${ }^{5}$

Defensor wrote between 632, the date of the death of Isidore of Seville who is the most recent author included in the text, and c. 750 , the approximate date of the oldest surviving manuscript. Ursinus has been identified with the monk who wrote the life of Leodegar, the martyred bishop of Autun.

Defensor's work consists of 81 chapters. The contents include the Christian virtues, prayer and confession, penance and fasting, almsgiving, tithes, monks, judges and doctors, bribes and gifts, rich and poor, master and slave, the brevity of this life, and finally reading itself. Each section begins with quotations from the Gospel, the apostles, Solomon and then the Church Fathers, who are sometimes identified. The most frequently used source is

Pattie for his generosity in sharing with me his full list of 255 manuscripts containing works of the Latin Ephraim. The clearest accounts of the Latin translation are by D. Hemmerdinger-Iliadou, "Ephrem latin," in Dictionnaire de Spiritualité 4 (1960): 815-22; Clavis Patrum Latinorum, pp. 1141-7 and in Patrologia Latina, Supplementum IV, cols. 604-48. None of the critical editions of Carolingian patristic writings identify Ephraim as a source.

2 E. C. Richardson (ed.), Hieronymi Liber de viris inlustribus. Gennadii Liber de viris inlustribus (Texte und Untersuchungen zur Geschichte der altchristlichen Literatur XIV; Leipzig, 1896) Cap. CXV, p. 51.

3 E. Rauner, "Notkers des Stammlers Notatio de illustribus viris," Mittellateinisches Jahrbuch 21 (1986): 34-69.

${ }^{4}$ H. Rochais (ed.), Defensoris Liber Scintillarum (Corpus Christianorum Series Latina; Turnhout, 1954).

5 Sed ne opus, quasi sine auctore, putetur apocrifum, unicuique sententiae per singula proprium scripsi auctorem. 
Isidore, then Gregory the Great, Augustine, Jerome and Basil, Ambrose and Cyprian, Caesarius of Arles, Clement, Ephraim, Hilary, Origen, and Eusebius.

Ephraim is explicitly quoted by Defensor at the end of his first chapter, "On Charity," where charity is described as the column and fortress of the holy soul. At the end of the chapter on the love of God and of neighbour, a passage attributed to Ephraim is quoted, a reference which Dom Rochais was unable to trace, where love of God frees man from the earth and God's love enlightens like the sweetest source. Earlier passages from Ephraim quoted in that chapter are derived from Isidore, Sententiae II 3, 4-5 and are not attributed to Ephraim. In chapter six, on compunction, Ephraim says that compunction is the health and illumination of the soul which draws down the Holy Spirit and makes Christ dwell in man. Where tears abound there sordid thoughts cannot reach. When we bear one another's burden we confound the devil and honour our Lord in heaven. The consolation of a brother when one is placed in tribulation of temptation is like a draught of water for someone thirsting in the heat of the sun. All this is excerpted from Ephraim's homily on the day of judgment.

Ephraim is also quoted against envy (Chapter XV, 28) and on clothing (Chapter XLIII) saying that rich vestments show we know only worldly things. Washing our face hands and feet excessively reveals that we are slaves of the vices.

The most extensive quotations are at the end of Defensor's long treatment of monks (Chapter 40). The soul of the monk is compared to a seed planted in good ground, or a lamp in a shady place at a time of psalmody and prayer. And the risks of sleep and envy and detraction. These passages come from the Admonitio ad Monachos. In chapter 64 on friends and enemies Dom Rochais noted an unidentified quotation on the loss of a faithful friend. ${ }^{6}$

Sermons 72 and 77 of Caesarius of Arles, are attributed to Ephraim in the manuscripts. They both deal with prayer and idle words and Dom Morin believed that Caesarius might have read some sermons of Ephraim. ${ }^{7}$ This would provide the earliest evidence for quotation of Ephraim in the Latin West.

${ }^{6}$ J. Kirchmeyer, D. Hemmerdinger-Iliadou, "S. Ephrem et le Liber Scintillarum," Revue des Sciences Religieuses 46 (1958): 545-50.

${ }^{7}$ Cf. G. Bardy, "Le Souvenir de S. Ephrem dans le haut moyen-âge latin," Revue du Moyen Age Latin 2 (1946): 297-300. 
To explain the presence and knowledge of Ephraim in Merovingian Gaul we must examine the manuscript evidence in detail. $^{8}$ The earliest surviving manuscript, Paris B.N.F. Lat. 12634 dates from the mid-sixth century, but it was at Corbie by the later ninth century. Ephraim is incorporated into a composite collection of monastic rules and sermons, a remarkable sixth-century manuscript, which includes one of the two early medieval copies of the Regula Magistri, excerpted with extracts from other monastic rules in a collection which has been unconvincingly linked to Eugippius. ${ }^{9}$ The monastic context is underlined by the title Admonitio ad Monachos given to the De Compunctione Cordis. The manuscript has always been regarded as Italian, though our knowledge of sixth-century manuscripts from Gaul is far from satisfactory. But that possibility is perhaps increased by the provenance of the second oldest manuscript, a set of fragments containing the De Compunctione and the Vitae Abrahae, preserved because they were used in the bindings of manuscripts from Corbie. ${ }^{10}$ They are copied in an informal half uncial script which Bischoff suggested might originate in Southern France. Each of these earliest manuscripts is the work of an important writing centre, early instances of book production for a monastic audience.

The remaining manuscripts fall into several groups. There are two distinctive collections, the Caesarius collection found in manuscripts from St. Omer, Bobbio, Metz and Southern Germany, in which sermons of Ephraim circulate with a collection of ten sermons by Caesarius of Arles which are designated Homiliae ad Monachos, and a German collection of sermons which includes

8 The material was first surveyed by A. Siegmund, Die Üeberlieferung der Griechischen Christlichen Literatur in der lateinischen Kirche bis zum zwölften Jahrbundert (Munich, 1949) 67-71.

9 H. Vanderhoven, F. Masai, P.B. Corbett, Regula Magistri Edition Diplomatique (Brussels: Scriptorium, 1953).

10 Codices Latini Antiquiores VI 708. Fragments are found in Amiens, Bibliothèque municipale, 12 and in Paris, Bibliothèque nationale, Lat. 10399 (fols 1-2); 13043; 12190; 13386 and Vatican, Biblioteca Apostolica Vaticana, Reg. Lat. 329; cf. B. Bischoff and V. Brown, "Addenda to Codices Latini Antiquiores," Medieval Studies XLVII (1985): 317-66, at p. 355. 
sermons attributed to Boniface ${ }^{11}$ and the sayings attributed to Ephraim.

A second Caesarius collection is found in an early ninthcentury manuscript from Laon, and a second copy from Werden, now in Berlin, which may have served as its exemplar. ${ }^{12}$ Here again the sermons may have been copied to be preached, rather than to serve as spiritual reading. But the presence of Ephraim's De Compunctione Cordis in three collections relating to virtues and vices (Paris B.N. Lat. 18095 Brussels B. R. 15111-128 and Vat. Lat. 650) suggests that his writings served as a guide to self-knowledge.

The popularity of Ephraim in Bavaria may reflect a sense that the sermons were particularly fitting in an area of more recent Christianization, or suggest the legacy of the Anglo-Saxon missionaries and so supplement the evidence for knowledge of Ephraim in Anglo-Saxon England presented by Jane Stevenson in Hugoye 1:2. Clm 6293 was copied at Freising under Bishop Atto c. $800 .{ }^{13}$ Another manuscript from the Freising cathedral library, which contains an Old High German version of the Lord's Prayer, was copied in Alemania at the start of the ninth century according to Bischoff. ${ }^{14}$ A further Bavarian manuscript, Clm 14634, was copied in Bavaria and came to the monastery of St. Emmeram at Regensburg, ${ }^{15}$ while Clm 19410 was copied in the diocese of Passau after $846 .{ }^{16}$ In addition to these South German manuscripts there is a central German group which may well reflect the place of Ephraim among Anglo-Saxon missionary foundations. Vat. Pal.

${ }^{11}$ I am grateful to Professor Arnold Angenendt for discussion of this collection, in connection with an unpublished leaf now in the Newberry Library in Chicago containing a sermon of Pseudo-Boniface.

12 J. Contreni, The School of Laon, 850-950: Its Manuscripts and Masters (Munich: Arbeo Gesellschaft, 1978) 52, 175. For the relationship between the Berlin and Laon manuscripts, cf. G. Morin (ed.), Sancti Caesarii Arelatensis Sermones (Corpus Christianorum Series Latina, CIII; Turnhout, 1953) xxvii, xxxviii-ix.

13 B. Bischoff, Die südostdeutschen Schreibschulen und Bibliotheken in der Karolingerzeit: I Die bayerischen Diözesen (Wiesbaden, 1974) $88 f$.

14 ibid., $145 \mathrm{f}$.

15 ibid., $239 f$.

16 ibid., 163f. B. Bischoff, Die südostdeutschen Schreibschulen und Bibliotheken in der Karolingerzeit: II Die vorwiegend österreichischen Diözesen (Wiesbaden, 1980) 2. 
Lat. 220 was copied somewhere on the middle or upper Rhine. ${ }^{17} \mathrm{It}$ contains the same collection of the sayings of Pseudo-Ephraim as Berlin, Phillipps 1716. Nürnberg, Germanisches Nationalmuseum HS 7152 is a single quire, containing the Ephraim corpus, which is also from the region of the River Main, copied in Anglo-Saxon script and dated to $c$. 800. Vat. Pal. Lat. 186 is one of the earliest manuscripts copied at Lorsch, in the insular script first used at the abbey. ${ }^{18}$

In addition to the surviving manuscripts Ephraim is listed in the Carolingian catalogues of Lorsch, Murbach, and St. Gall, and at Bobbio. ${ }^{19}$ The reference to the Liber Sancti Effrem in the earliest Fulda catalogue is remarkably early and perhaps belongs with the missionary evidence discussed above.

Ephraem is found in a context of monastic spirituality in the Paris manuscript with the Rules of Serapion, Augustine and the Master, and at Werden with the Rule of Basil. Pseudo-Ephraim was copied with the Rule of Benedict in the Southern French manuscript now in Verona. Paris B.N. Lat 13440, a very small format patristic collection, may have been made for use in a nunnery, since it includes the selection of patristic texts excerpted at Aachen in 816, which is prefaced by a rule for nuns. (The volume also has a sermon on the ten virgins.) The Werden manuscript also includes 816 legislation, so perhaps there is a link between the reform councils at the start of Louis the Pious and an interest in Ephraim.

The tenth-century Brussels manuscript B. R. 1831-33 is in a Carolingian binding. The first page (f. 40r) of Hincmar's treatise looks like the first page of a separate manuscript but there is no clear indication that it was an opening page. The first page of the Ephraem (f1 r) starts after the end of a sermon which is now truncated. The reason for combining Ephraim with Hincmar is far from clear, and though the binding is original it has been repaired. ${ }^{20}$ Still less is known about the other tenth-century

17 B. Bischoff, Lorsch im Spiegel ibrer Handschriften (1989) 57.

18 Bischoff, Lorsch, 31.

19 Siegmund, 68f.

20 The first folio is illustrated in L. Gilissen, La Reliure occidentale antérieure à 1400 d'après les manuscrits de la Bibliothèque royale Albert 1er à Bruxelles (Turnhout, 1983), plate XLIII; the structure of the volume and the anomalies of its construction are discussed on pp. 95-100. 
manuscripts, though Brussels B. R. 15111-128 also seems to fit a monastic context.

Hemmerdinger-Iliadou found a quotation from the Latin Ephraim in the Diadema Monachorum of Smaragdus of St. Mihiel. ${ }^{21}$ P. Fransen identified extracts in the collection of patristic materials assembled by Florus of Lyons. 22 This suggests a context of monastic spirituality comparable to that found in Defensor. The excerpts from Ephraim in Paris, B. N. Lat 18095 and a passage in Angers, B. M. 279 f. $3 \mathrm{v}$ show the survival of this tradition of excerpts. But Ephraim's writings were also copied as a corpus, which survives in fifteen ninth or tenth-century manuscripts. Until further borrowings have been securely identified, speculative assertions about the influence of Ephraim on Anglo-Saxon or Old High German literature are ill-advised. We know too little about his status: the important work remains to be done.

\section{SURVIVING MANUSCRIPTS OF THE LATIN EPHRAIM COPIED BEFORE $C .1030$}

\section{[Abbreviations for the Ephraim Corpus}

\begin{tabular}{|c|c|}
\hline com. 1 and 2 & $\begin{array}{l}\text { de compunctione cordis, "on the compunction of } \\
\text { the heart," } 1-2\end{array}$ \\
\hline bea. & $\begin{array}{l}\text { de beatudine animae, "on the blessed state of the } \\
\text { soul" }\end{array}$ \\
\hline iud. & de die iudicii, "on the day of judgement" \\
\hline luct. & in luctaminibus, "in struggles" \\
\hline paen. & de paenitentia, "on penitence" \\
\hline res. & de resurrectione, "on the resurrection" \\
\hline v.Abr. & vita Abrahae, "the life of Abraham”] \\
\hline
\end{tabular}

Paris, B. N. Lat. 12634 (CLA 646): Serapion regula, Evagrius sententiae, Augustinus regula, "regula Eugippii," Ephraim com. 1, com. 2, Johannes Chrysostom de consolatione mortis, Augustinus sermo de latrone, Passio Johannis et Pauli. Italy s. VI, Corbie c. 850.

Paris, B. N. Lat 10399 + Amiens 12 + Vat. Reg. Lat. 329 + fragments in B. N. Lat 12190 and B. N. Lat 13386 (CLA 106b):

21 PL 102, 680-1.

22 P. I. Fransen, "Les Extraits d'Ephrem Latinus dans la compilation des XII pères de Florus de Lyon,” Revue Bénédictine 87 (1977): 349-71. 
Fragments of v.Abr. + com. Southern France $c .700$, at Corbie by 800.

Paris, B. N. Lat 13348 (CLA 656): Jerome in Genesim, Jerome de situ et nominibus, Eucherius, Ps.-Ephraim de fine mundi, Pseudo-Methodius. Corbie “en' script s. VIII 3/4.

St. Gall, 108 (CLA 905): Isidore, Ps.-Ephraim de fine mundi, Ps.-Jerome in Psalmos. West Switzerland or North Italy s. VIII ex.

Vatican, Barb. Lat. 671 (CLA 64): Isidorus de fide catholica, Ephraim res., bea., pae., luct., iud., com. 2, de fine mundi, Gennadius de ecclesiasticis dogmatibus. Italy s. VIII.

Bern, 289 (CLA 861): ordo romanus 1, Isidore de viris illustribus, Ephraim iud., Martin of Braga, martyrologium Hieronymianum. Metz s. VIII/IX.

Karlsruhe, Reichenau Frag. 79: Augustinus Sermo, Ephraim iud. s. VIII/IX.

Paris, B. N. Lat 13440 (CLA 662) “ab'-Scriptorium (cf. D. Ganz, Corbie in the Carolingian Renaissance (Sigmaringen, 1990) 48-56): Ephraim com. 1 and 2, Pseudo-Ambrosius, Columbanus, florilegium of patristic texts from the regula sanctimonialium of 816. Northern France, c. 816; later at Corbie.

The St. Omer/Turin family with ten homiliae ad monachos of Caesarius of Arles. Same collection as Turin, G v 7 and Metz, 134 and $\mathrm{Clm} 6330$.

Metz, B. M. 134 (CLA 788), destroyed in 1944: Ephraim homiliae III, excerpts from Isidore synonima and sententiae, Caesarius, and Gregory regula pastoralis, homiliae, grammatica, glossary. s. VIIII ex.

St. Omer, 33-bis: Hieronymus in Matthaeum, Caesarius homiliae X (lacking the first), Ephraim paen., res., bea., iud., luct., "Paulinus de passionibus animarum' (in fact Jerome de persecutionibus Christianorum) (Clavis 606). St. Bertin s. IX in.

Turin, Bibl. Naz. Universitaria G v 7: Caesarius homiliae, Ephraim paen., res., bea., iud., luct. Bobbio s. IX.

Munich, Clm. 6330: Ephraim bea., pae., iud. Doctrina Diversarum Patrum, including Caesarius, Isidore synonima. Alemania s. IX; later at Freising (Bischoff, Schreibscbulen I, 145f.).

Nürnberg, Germanisches Nationalmuseum HS 7512 (CLA 1346): Ephraim com. 1 and 2. Insular scriptorium on the continent, region of the River Main $c .800$. 
Vatican, Pal. Lat. 186: Ephraim de paen. Lorsch s. IX in. (Bischoff, Lorsch, 31).

Karlsruhe, Aug. CXCVI: Isidore liber soliloquiorum, Ps.Ephraim de fine mundi, Ppoentientiale. Reichenau s. IX.

Munich, Clm. 19410: Alcuinus carmina, Ephraim iud., glossae. ?Passau s. IX med. (Bischoff, Schreibschulen I, 163f.; II, 2).

Vatican, Pal. Lat. 556: Augustinus homiliae XVIII, Ps.Ephraim iud. s. IX.

Troyes, B. M. 898, part 1: Ephraim res., bea., luct., paen. s. IX.

Montpellier, Bibl. Interuniversitaire H 404: Alcuinus de ratione animae, in psalmos poenitentiales, in canticum gradum, Ephraim com. 1, com. 2. s. IX 3/4. Copied by Manno of St. Oyan.

Paris, B. N. Lat 18095: Alcuinus de virtutibus et vitiis, Fulgentius sermo, Pseudo-Cyprian de XII abusivis saeculi, excerpts from Chrysostom, Athanasius, Epiphanius, Ephraim, Gregory of Nyssa, excerpta patristica de oratione, versus Colmani et Columbani, Augustinus sermones, Ephraim de munditia animae, visio Wettini, Beda visio Drycthelmi. Northern France s. IX med.

Munich, Clm. 14364: Ps.-Augustinus sermo, Ephraim res., bea., paen., luct., iud., com. 1, com. 2, Caesarius vitae sanctorum. Bavaria s. IX (Bischoff, Schreibschulen I, 239f.).

St. Gall, 92: Ephraim res., bea., paen., luct., iud, monita, com. 1, com. 2, admonitio. St. Gall s. IX 4/4.

St. Gall, 93: Ephraim com. 1, com. 2, res., bea., paen., luct. St. Gall s. IX 4/4.

Berlin, Theol. fol. 355: capitulare monasticum of 816, Ephraim com. 1, com. 2, res., bea., paen., luct., iud., Caesarius sermones XXV, Basilius regula. Northern France to Werden s. IX (same collection as Laon 121).

Laon, 121: Caesarius sermones XXV, Ephraim com. 1, com. 2, res., bea., pae., luct., iud., Gregory. North-Eastern France s. IX (according to Morin, this is a copy of Berlin, Theol. fol. 355).

\section{Tenth-Century Manuscripts}

Brussels, B. R. 1831-33: Ephraim res., bea., paen., luct., iud., com. 1, com. 2, Hincmar contra Goteschalcum de trinitate. Rheims s. X.

Brussels, B. R. 15111-128: martyrologium, glossae super regula Benedicti, Alcuin de virtutibus et vitiis, Ephraim com. 1, com. 2, Cassian. s. X. 
Munich, Clm 3717: vita Eligii + Ephraim obsecro, res., bea., paen., luct., iud., com. Augsburg s. X.

London, B. L. Harley 3060: Julian of Toledo, Ephraim res., bea., paen., luct., iud., com. 1, com. 2. France s. X.

Ghent, 307: Smaragdus diadema monachorum, vitae sanctorum, Ephraim iud. Trier s. X.

Vatican, Lat. 650: Alcuinus de trinitate, Fulgentius de fide ad Petrum, Hieronymus excerpta, Nilus de octo vitiis, Alcuinus de vitiis, Cassian collatio V, Gregorius in Cant., Origines in Cant., Ephraim com. 1, com. 2, Ps.-Basilius admonitio. s. X.

Munich, Clm. 18583: Ephraim com. 1, com. 2, paen., luct., iud. Tegernsee c. 1030.

\section{Manuscripts of Pseudo-Ephraim Dicta, or "Sayings" (Clavis 1145)}

Munich, Clm. 6293 (CLA 1262): vitae patrum, Ephraim dicta 1 and 2, sermones. Freising before 811 (Bischoff, Schreibschulen I, 88f.).

Vatican, Pal. Lat. 212 (CLA 85): Ephraim dicta 1, 2 and 3. Germany s. VIII ex.

Vatican, Pal. Lat. 220: Ephraim dicta 1, 2 and 3. Middle Rhine s. IX.

Berlin, Phillipps 49 (1716): sermones, Ephraim dicta, de symbolo, Ps.-Augustinus sermones, glossae. s. IX in.

\section{Text Ascribed to Ephraim}

Verona, Bibl. Capitolare LII (CLA 505): Augustini et Gregorii homiliae, regula Benedicti, Ephraim $\mathrm{O}$ admirabiles viri festinate, liber pontificalis. Burgundy s. VIIII.

\section{REFERENCES}

CLA = Lowe, E. A. Codices Latini Antiquiores I-XI and Supplement (Oxford, 1934-71).

Bischoff, Schreibschulen = Bischoff, B. Die südostdeutschen Schreibschulen und Bibliotheken I: Die bayerischen Diözesen (Wiesbaden, 1974); II Die vorviegend österreichischen Diözesen (Wiesbaden, 1980). 